\title{
The assessing of the quality of geothermal reservoirs on the example of the Lower Triassic aquifer in the Mogilno-Łódź Trough (Polish Lowlands)
}

\author{
Aleksandra Kasztelewicz, ${ }^{1, *}$ and Barbara Tomaszewska ${ }^{2}$ \\ ${ }^{1}$ AGH University of Science and Technology, Faculty of Geology Geophysics and Environmental \\ Protection, Mickiewicza 30, 30-059 Kraków, Poland \\ ${ }^{2}$ Mineral Energy Economy Research Institute PAS, Wybickiego 7A, 31-261 Kraków, Poland
}

\begin{abstract}
Petrographic and petrophysical investigations of the aquifers allow to estimate their productivity and infectivity, as well as allow for better recognition of the origin of the chemical composition of geothermal waters. Deep deposition of the Lower Triassic sediments in the analysed area (locally above $5000 \mathrm{~m}$ b.s.l.) is conducive to high temperatures (above $90^{\circ} \mathrm{C}$ ) within the reservoir and causes deterioration of reservoir parameters. The Lower Triassic geothermal reservoir consists of fine and mixed grainsize sands and sandstones layers from 10 to $650 \mathrm{~m}$ thick; depending on the depth. The water within the reservoir exhibits mineralization ranging from 2 to over $100 \mathrm{~g} \mathrm{~L}-1$ and its temperature ranges from 30 to $100^{\circ} \mathrm{C}$. The mineralization of waters varies from $140 \mathrm{~g} / \mathrm{dm} 3$ (Warsaw basin) to over $350 \mathrm{~g} / \mathrm{dm} 3$ in the deep zones of the basin (axial fragments of the Mogileńsko-Łódź trough). The average permeability of reservoir layers in the Polish Lowlands is $145.5 \mathrm{mD}$.
\end{abstract}

\section{Introduction}

In the last few decades there has been an increase in interest in geothermal energy in Poland. Nowadays, geothermal energy is mainly used for heating purposes in recreation and balneotherapy, what has been expressed by seven new centres open in recent years [15]. Despite this, it should be noted that the exploration of geothermal energy carries the risk of not finding suitable subsurface reservoirs. Success of the of the geothermal projects base on ability to understand and mitigate the uncertainties associated with subsurface environment. The paper focused on important aspect of geological identification of the structural characteristic of reservoir rocks as one of the most important elements of the geological research work.

\footnotetext{
*Corresponding author: akasztel@agh.edu.pl
} 


\section{Geological background}

The area selected for detailed analyses covered the central part of Poland (Mogilno-Łódź Trough region, Fig. 1). The Lower Triassic geothermal reservoir consists of fine and mixed grain-size sands and sandstones layers from 10 to $650 \mathrm{~m}$ thick; depending on the depth. In the perspective area, the top of the Lower Triassic formation is located at depths of about 2,200 m, b.g.l. to over $5000 \mathrm{~m}$ b.g.l. in the axial part of the Mogilno-Łódź Trough. The depth of deposition of aquifers contributes to the high temperatures prevailing within the Lower Triassic reservoir. The water within the reservoir exhibits mineralization ranging from 2 to over $100 \mathrm{~g} \mathrm{~L}-1$ and its temperature ranges from 30 to $100^{\circ} \mathrm{C}$. The mineralization of waters varies from $140 \mathrm{~g} / \mathrm{dm}^{3}$ (Warsaw basin) to over $350 \mathrm{~g} / \mathrm{dm}^{3}$ in the deep zones of the basin (axial fragments of the Mogileńsko-Łódź Trough). The average permeability of reservoir layers in the Polish Lowlands is $145.5 \mathrm{mD}$ The depth of deposition of aquifers contributes to the high temperatures prevailing within the Lower Triassic reservoir [6-8].

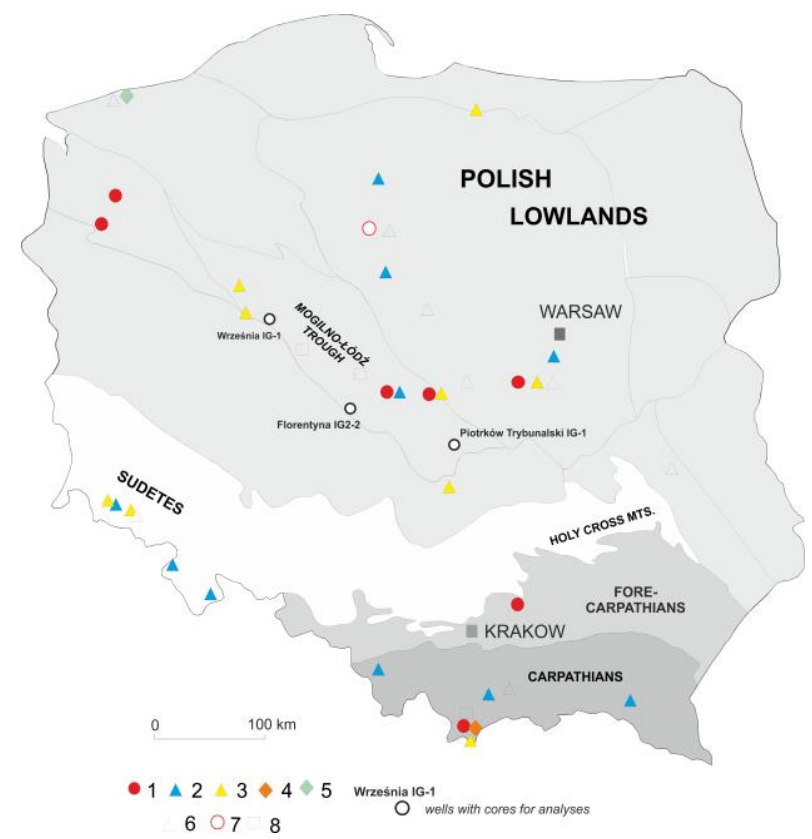

Fig. 1. Location of the examinated boreholes and geothermal energy applications in Poland (based on [5]) 1 - district heating systems, 2 - health resorts, 3 - recreation centres, 4 - wood drying, 5 - fish farming, 6 -recreation centres in realization, 7 - heating system at early stage, 8 - some planned cogeneration plats

\section{Methods}

In order to recognize parameters of rocks that form potential deep reservoirs, 8 samples of the Lower Triassic rock formations were collected from the 3 borehole cores: Września IG1, Florentyna IG-2, and Pitorków Trybunalski IG-1. A small number of samples resulted from the limitations of the size of cores in archives. Collected for detailed mineralogical, petrographic study cores had to meet the size requirements for microscopic examination. Basic parameters such as porosity, permeability, specific surface area have been identified. Thin sections were used for microscopic and pore analysis. Laboratory studies included macroscopic and microscopic observations. Rock samples were subject to microscopic 
optical examination, accompanied by scanning electron microscopy (SEM) and X-ray diffraction inspections (XRD). Porosity analysis of the rocks examined was carried out through petrophysical inspections of rocks by means of measurements of capillary action.

\section{Results and discussion}

Rock samples occurring within the Lower Triassic form show large petrographic variations. In the profile from Września IG-1: $2387.5 \mathrm{~m}$ b.g.l. allochthonous limestone was observed (Fig. 2a) and from the depth of $2728.4 \mathrm{~m}$ b.g.l. occurs mudstones (Fig. 2b,c). In the profile of Florentyna IG-2 - subarkose arenites (Fig. 2d). Large petrographic differentiation also occurs in the Piotrków Trybunalski profile. Sample from depth $3746.1 \mathrm{~m}$ b.g.l. represents anhydrite (Fig. 2e), from $3920.0 \mathrm{~m}$ b.g.1. and $4193.1 \mathrm{~m}$ b.g.1. quartzite sandstones (Fig. 2f).

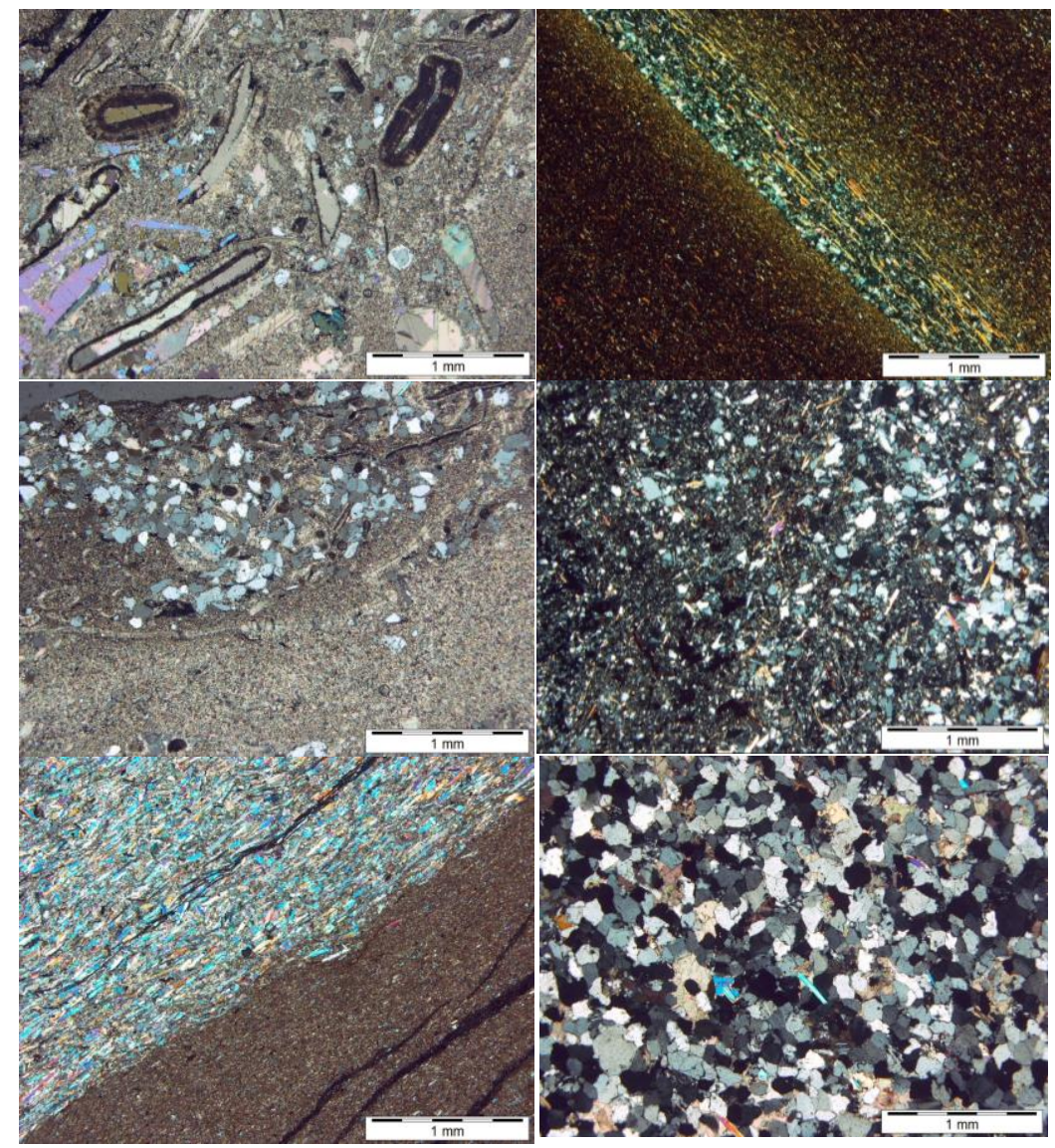

Fig. 2. Transmitted light microscopic images of rock samples from Lower Triassic formations, crossed polarizers: a - oncoids in limestone (Września IG-1: $2387.5 \mathrm{~m}$ b.g.1.), b - mudstone with marked laminated texture (Września IG-1: $2728.4 \mathrm{~m}$ b.g.l.), c - insert of cluster material (Września IG-1: $2387.5 \mathrm{~m}$ b.g.1.), d - grain skeleton of sandstone (Florentyna IG-2: $2698.5 \mathrm{~m}$ b.g.l.), e anhydrite present in lighter laminates (Piotrków Trybunalski IG-1: $3746.1 \mathrm{~m}$ b.g.l.), f - carbonate binder in sandstone (Piotrków Trybunalski IG-1: 3920.0 m b.g.l.)

A scanning electron microscopy confirms different mineral composition and petrographic character of the exanimated rock samples. In the Września IG-1: $2387.5 \mathrm{~m}$ b.g.l. the main 
mineral is calcite accompanied by anhydrite (Fig 3a). The samples taken from the Florentyna IG-2 profile are mainly sandstones, where a large quantitative branch has mica formed in the form of muscovite (Fig. 3b). Petrographic variability can also be seen in the Piotrków Trybunalski profile. In the sample from the depth of $3746.1 \mathrm{~m} \mathrm{b.g.1.} \mathrm{occurs}$ anhydrite (Fig. 3c) accompanied by dolomite, while in the other two are sandstones in which the grain skeleton also contains muscovite with inclusions of apatite grains (Fig. 3d).
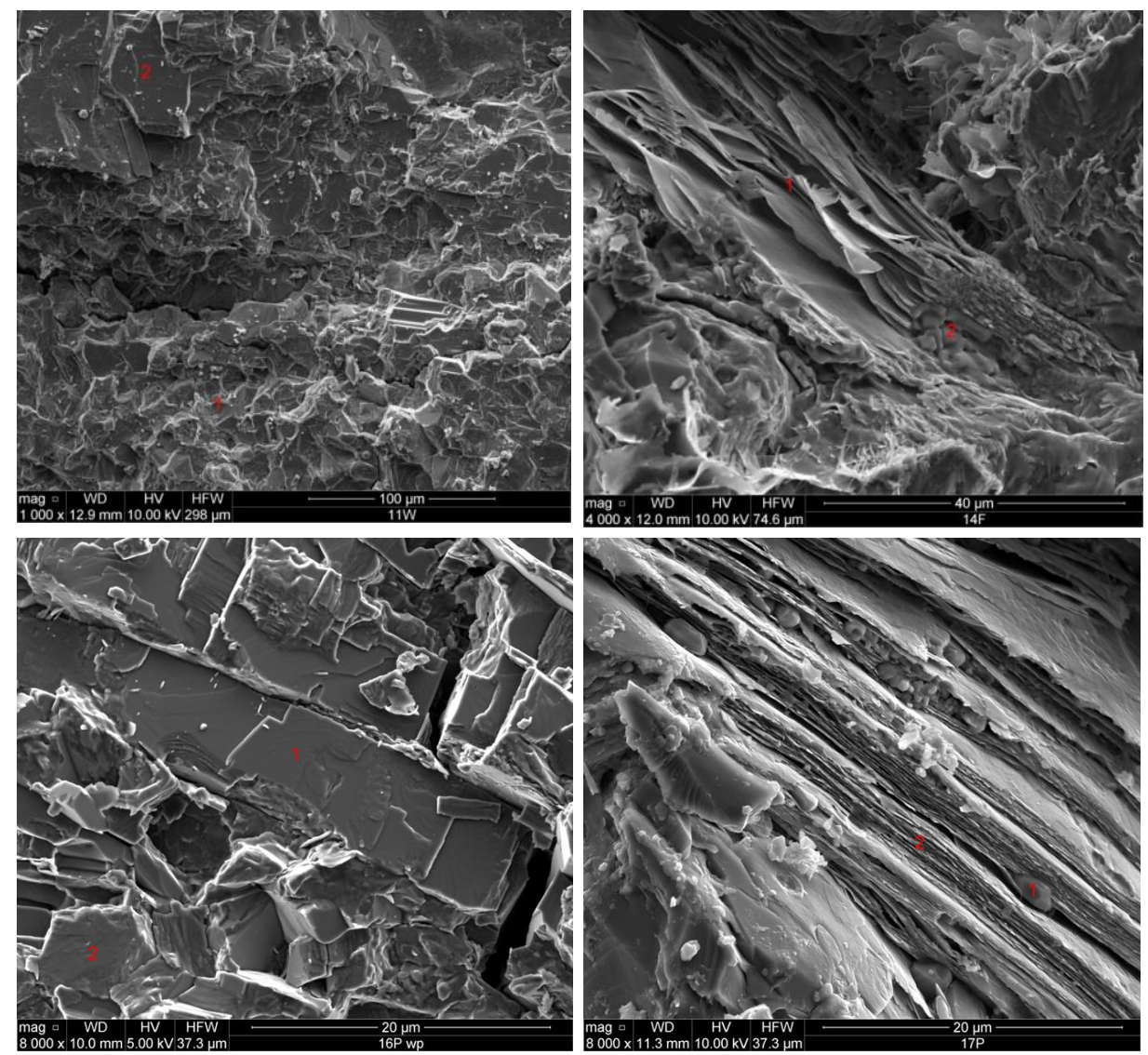

Fig. 3. Microstructures of rock samples found in the Lower Triassic profile: a - calcite grains (Września IG-1: $2387.5 \mathrm{~m}$ b.g.l.); b - muscovite sheets (Florentyna IG-2: $2698.5 \mathrm{~m}$ b.g.l.); $\mathrm{c}$ - anhydrite grains (Piotrków Trybunalski IG-1: $3746.1 \mathrm{~m}$ b.g.1.); $\mathrm{d}$ - biotite with apatite appendages (Piotrków Trybunalski IG-1: 3920.0 m b.g.l.)

Observations in the polarization and scanning microscope have been confirmed by diffraction analysis. The mineral composition of selected rock samples from the Lower Triassic sediment profile is shown in Figure 4.

The results of petrophysic analysis is presented in table 1 . The total porosity of the studied rocks ranges from 0.25 to $11.9 \%$, effective porosity from 0.23 to $11.34 \%$. The surface area varies from 0.19 to $4.33 \mathrm{~m}^{2} / \mathrm{g}$. Samples from Września IG-1 (2387.5 m b.g.l.), Piotrków Trybunalski IG-1 (3746.0 m b.g.1.) and Florentyna IG-2 (2990.0 m b.g.1.) porosity ranges from 0.25 to $0.55 \%$. The size of the specific surface area for these samples is $0.0 \mathrm{~m}^{2} / \mathrm{g}$, which may indicate the occurrence of micro-voids. 


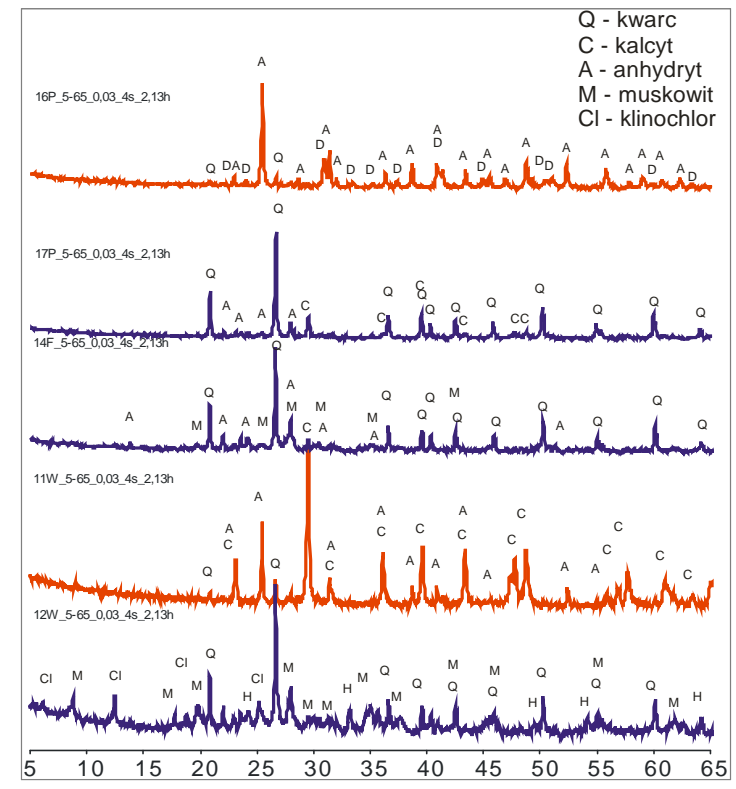

Fig. 4. Diffractograms of the mineral composition of rock samples from the Lower Triassic formations

Table 1. Average values of petrophyscial parameters of rocks in the well sections analyse

\begin{tabular}{|c|c|c|c|c|c|c|c|c|c|c|c|}
\hline \multirow{2}{*}{ 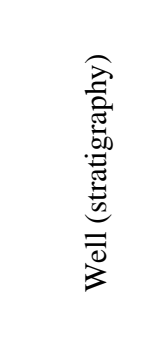 } & \multirow{2}{*}{ 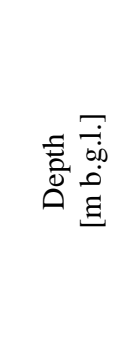 } & \multirow{2}{*}{ 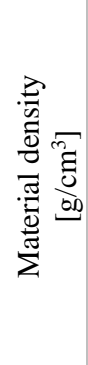 } & \multirow{2}{*}{ 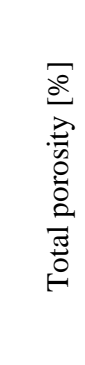 } & \multirow{2}{*}{ 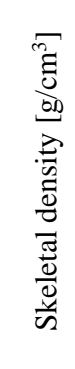 } & \multirow{2}{*}{ 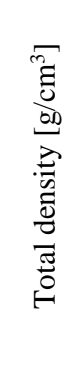 } & \multirow{2}{*}{ 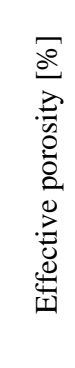 } & \multirow{2}{*}{ 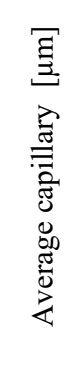 } & \multirow{2}{*}{ 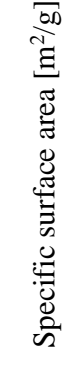 } & \multirow{2}{*}{ 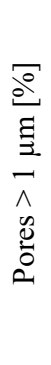 } & \multicolumn{2}{|c|}{ 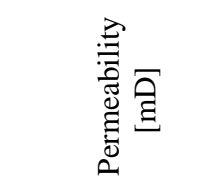 } \\
\hline & & & & & & & & & & $x$ & $N$ \\
\hline $\begin{array}{l}\text { Września } \\
\text { IG-1 }\end{array}$ & 2387.50 & 2.77 & 0.25 & 2.68 & 2.67 & 0.23 & 0.00 & 0.00 & - & 0.033 & $<0.007$ \\
\hline $\begin{array}{l}\text { Września } \\
\text { IG-1 }\end{array}$ & 2728.40 & 2.83 & 1.49 & 2.69 & 2.66 & 1.31 & $\begin{array}{c}0.02 \\
1\end{array}$ & 1.21 & 31 & 0.001 & - \\
\hline $\begin{array}{l}\text { Piotrków } \\
\text { Tryb. IG-1 }\end{array}$ & 3746.0 & 2.96 & 0.38 & 2.83 & 2.82 & 0.34 & 0.00 & 0.00 & - & $\begin{array}{c}<0.00 \\
8\end{array}$ & 0.001 \\
\hline $\begin{array}{l}\text { Piotrków } \\
\text { Tryb. IG-1 }\end{array}$ & 3920.0 & 2.7 & 3.09 & 2.6 & 2.53 & 2.8 & 0.23 & 0.19 & 19 & 0.041 & 0.038 \\
\hline $\begin{array}{l}\text { Piotrków } \\
\text { Tryb. IG-1 }\end{array}$ & 4193.1 & 2.72 & 3.99 & 2.62 & 2.52 & 3.63 & 0.11 & 0.52 & 35 & 0.389 & 0.095 \\
\hline $\begin{array}{l}\text { Florentyna } \\
\text { IG-2 }\end{array}$ & 2698.5 & 2.78 & 7.47 & 2.65 & 2.48 & 6.64 & 0.02 & 4.33 & 11 & 0.200 & - \\
\hline
\end{tabular}




\begin{tabular}{|l|c|c|c|c|c|c|c|c|c|c|c|}
\hline $\begin{array}{l}\text { Florentyna } \\
\text { IG-2 }\end{array}$ & 2774.2 & 2.7 & 11.9 & 2.66 & 2.35 & $\begin{array}{c}11.3 \\
4\end{array}$ & 0.11 & 1.83 & 13 & 0.132 & 0.014 \\
\hline $\begin{array}{l}\text { Florentyna } \\
\text { IG-2 }\end{array}$ & 2993.0 & 2.72 & 0.55 & 2.56 & 2.55 & 0.47 & 0.00 & 0.00 & 11 & 0.200 & - \\
\hline
\end{tabular}

Based on the amount of permeability $(>0)$, it can be concluded that these samples are nonporous, and the permeability is related to the micro-voids that occur in them. Samples from Września IG-1 (2728.5 m b.g.l.) and Florentyna IG-2 (2698.5 m b.g.l. and $2744.2 \mathrm{~m}$ b.g.l.) have a specific surface area above $1 \mathrm{~m}^{2} / \mathrm{g}$. The size of porosity and specific surface indicates the microporous character of the pore space. Parallel permeability in the analyzed rocks contain from 0.001 to $0.389 \mathrm{mD}$, perpendicular permeability ranges from 0.001 to $0.095 \mathrm{mD}$. In these samples, the surface area is zero, non-zero permeabilities are the result of the occurrence of microfissures.

Analyzing the values of porosity and permeability, samples with a porosity below $1 \%$ can be considered as sealing rocks, samples with a porosity higher than $1 \%$ can be classified as moderately good reservoir rocks.

\section{Conclusions}

Petrographic and petrophysical investigations of the geothermal aquifers allow to estimate their productivity. Presented results of the petrographic and petrophysical analysis of the cores from Lower Triassic come from the selected boreholes located in the Mogilno-Łódź Trough in the Polish Lowlands. Presented investigations have confirmed that sedimentary rocks in the central part of Poland, at depths above 2,200 $\mathrm{m}$ below surface, are characterised by low values of porosity and permeability. The results of the petrographic and mineralogical studies of core samples showed that in the selected area rather poor reservoir parameters should be expected, translating into low efficiency of boreholes.

The research was carried out at the request of the Ministry of Environment and financed by the National Found for Environmental and Water Management No 398/2011/Wn-06/FG-hg-tx/D. The work was financed by the Polish Geothermal Society

\section{References}

1. B. Kępińska Geothermal Energy Use - Country Update Report from Poland, 2010-2015, EGC Proceedings, Strasbourg, France (2016).

2. W. Górecki, A. Sowiżdżał, M. Hajto, A. Wachowicz-Pyzik, Environ Earth Sci 74 (2015)

3. E. Hałaj, Environ Earth Sci 74 (2015)

4. A. Sowiżdżał Renew Sust Energ Rev 82 (2018)

5. B. Kępińska Geological Exploration Technology, 261 (2018)

6. W. Górecki (ed.) Atlas of geothermal resources of Mesozoic formations in the Polish Lowlands (Kraków, 2006)

7. A. Sowiżdżał, B. Papiernik, G. Machowski, M. Hajto, Geol Q, 57, 4 (2013)

8. B. Tomaszewska (ed.) Atlas of the possible use of geothermal waters for combined production of electricity and heat using binary systems in Poland (MEERI PAS, Kraków, 2014) 